\title{
Androgen Receptor Inhibitor
}

National Cancer Institute

\section{Source}

National Cancer Institute. Androgen Receptor Inhibitor. NCI Thesaurus. Code C146993.

Any agent that inhibits the activity of the androgen receptor (AR). 